\title{
The effectiveness of computerized clinical guidelines in the process of care: a systematic review
}

\author{
Gianfranco Damiani ${ }^{1 *}$, Luigi Pinnarelli ${ }^{2}$, Simona C Colosimo ${ }^{1}$, Roberta Almiento ${ }^{1}$, Lorella Sicuro ${ }^{1}$, Rocco Galasso ${ }^{3}$, \\ Lorenzo Sommella ${ }^{2}$, Walter Ricciardi ${ }^{1}$
}

\begin{abstract}
Background: Clinical practice guidelines have been developed aiming to improve the quality of care. The implementation of the computerized clinical guidelines (CCG) has been supported by the development of computerized clinical decision support systems.

This systematic review assesses the impact of CCG on the process of care compared with non-computerized clinical guidelines.

Methods: Specific features of CCG were studied through an extensive search of scientific literature, querying electronic databases: Pubmed/Medline, Embase and Cochrane Controlled Trials Register. A multivariable logistic regression was carried out to evaluate the association of CCG's features with positive effect on the process of care.

Results: Forty-five articles were selected. The logistic model showed that Automatic provision of recommendation in electronic version as part of clinician workflow (Odds Ratio [OR] $=17.5 ;$; 95\% confidence interval [Cl]: 1.6-193.7) and Publication Year (OR $=6.7 ; 95 \% \mathrm{Cl}: 1.3-34.3)$ were statistically significant predictors.

Conclusions: From the research that has been carried out, we can conclude that after implementation of CCG significant improvements in process of care are shown. Our findings also suggest clinicians, managers and other health care decision makers which features of CCG might improve the structure of computerized system.
\end{abstract}

\section{Background}

Clinical practice guidelines have been developed to improve the quality of care, patient access, treatment outcomes, appropriateness of care and achieve cost containment by improving the cost benefit ratio [1-4].

At the same time many healthcare organizations have widely promoted the development of computerized clinical decision support systems (CDSS) with the aim of improving practitioners' performance [5-7].

According to the indications of regulatory systems, professional bodies and consumer organizations, CDSS can also support the implementation of the computerized clinical guidelines (CCG) [8].

An effective model of CCG consists of computer accessibility, patient-specific reminders in the clinician's

\footnotetext{
* Correspondence: gdamiani@rm.unicatt.it
'Department of Public Health-Università Cattolica Sacro Cuore-Rome, Largo

* Correspondence: gdamiani@rm.unicatt.it
${ }^{1}$ Department of Public Health-Università Cattolica Sacro Cuore-Rome, Largo Francesco Vito 1, 00168, Rome, Italy
}

(C) 2010 Damiani et al; licensee BioMed Central Ltd. This is an Open Access article distributed under the terms of the Creative Commons

workflow and its integration with medical records, as demonstrated by Wang et al. [9].

Even though different studies in literature are focused on demonstrating that CDSS can have an impact on physicians' behaviour regarding to patients' care [6,10-12], there are very little evidence about the effectiveness of electronic guidelines [13-15] and impact of computerized support on implementing of clinical recommendations. In a qualitative systematic review, Shiffman et al. [13] highlighted higher effect of CCG versus non-electronic systems. Due to the lack of studies containing quantitative evaluation, research was focused on a systematic review of available literature about the impact of CCG upon the process of care compared with non-computerized clinical guidelines (NCCG) (such as paper guidelines, peer-to-peer consultation and previous experience.). Moreover, were analysed specific features 
of the computerized guidelines which are potentially linked with the improvement of the process of care.

\section{Methods}

\section{Search strategy}

An extensive search of scientific literature was carried out querying electronic databases to identify relevant studies: Pubmed/Medline, Embase and Cochrane Controlled Trials Register. The search covered the period from January 1992 to March 2006. The search of articles were carried out using the following key words, related to:

1. Exposure variables: computerized clinical guidelines, computer-based guidelines, computerized clinical recommendations, computer decision support aids, software guidelines, computerized clinical pathways, computerized critical pathways, computerbased pathway*, electronic care map, electronic care pathways, electronic clinical pathways, electronic critical pathways, integrated care pathway, electronic clinical reminder, electronic clinical reminders, electronic reminder AND practice guidelines AND electronic medical record, computerized reminders AND guidelines;

2. Effect variables: medical outcomes, organisation's outcomes, patients' outcomes; process of care

3. Population variables: medical doctors, health personnel.

The search in grey literature was carried out using general purpose search engines (GOOGLE, VIVISIMO) in order to identify missing articles. Rest of the articles were identified through the analysis of bibliographic citations.

\section{Inclusion and exclusion criteria}

Considering study's design, only experimental or analytical studies were included while descriptive studies were excluded. The main exposure variable in our research was the comparison between CCG and NCCG (such as paper guidelines, peer-to-peer consultation and previous experience). Papers which did not contain comparison between CCG and NCCG were excluded from analysis. So, only the papers in which the guidelines were coming from a scientific society recommendations or approved by a National body, a scientific society, union or corporation of physicians or universities were included in this study. Articles not matching these criteria were excluded. Also, only articles focusing on adult patients (age $\geq 18$ years) were taken into consideration. Studies involving children and adolescents (age $<18$ years) were excluded due to the fact that there are specific factors linked with the paediatricians adherence to guidelines in this specific age group [16-18].

\section{Study selection}

Titles and abstracts of the selected studies were reviewed independently by two authors (C.S.C and A.R.) and were rated as "potentially relevant" or "not relevant" using search strategies based on study design, subjects and type of intervention. If one of the reviewers considered a reference potentially relevant, full-text articles were retrieved and examined independently, using the full set of inclusion and exclusion criteria to select the final number of studies for research. Disagreements between reviewers were resolved by discussion or by third author (G.D.).

\section{Data extraction}

Two reviewers (C.S.C. and A.R.) assessed whether the use of computerized guidelines was going to improve the process of care and evaluated the positive or negative impact of computerized guidelines on the process of care.

Afterwards, the outcomes were distributed in two groups: favouring CCG and favouring NCCG based on evaluation of results of inference analysis. Then, the effect of computerized guidelines was defined as positive when reported improvement was more than $50 \%$ of the outcomes. Effect was defined as negative when the improvement was equal or less than $50 \%$ of the outcomes. Positive or negative effects of computerized guidelines were confirmed according to the authors' judgment in the conclusions' section of each single paper. Finally, were analysed the variables potentially linked to positive effect on the process of care. Some variables were not included in the analysis because it was not possible to obtain them from most studies (patients' age, health care givers' age, health care providers' degree, duration of observation). The analysed system's features were identified referring to Kawamoto [12] or they were extracted by the authors from the studies. So, 21 features related to the following categories were analysed:

- General system features;

- Clinician-system interaction features;

- Communication content features;

- Auxiliary features;

- Guidelines features.

The description of each feature is reported in Table 1.

\section{Quality assessment}

The methodology of each study was assessed independently by two authors (C.S. and A.R.) according to a score assessing five potential sources of study bias [10,19-21]. Disagreements were solved by consulting the third author (G.D.) or according to a consensus. The studies were evaluated using following system: 
Table 1 Description of 21 CCG's features in five categories and proportion" of study containing each feature

\begin{tabular}{|c|c|c|c|}
\hline CATEGORY & FEATURE & EXPLANATION & PROPORTION \\
\hline \multirow[t]{4}{*}{$\begin{array}{l}\text { General system } \\
\text { features }\end{array}$} & Presence of networks * & $\begin{array}{l}\text { User has access to recommendation in computer terminals, } \\
\text { available at several workstations in the hospital. }\end{array}$ & 0.20 \\
\hline & Type of suggestion * & $\begin{array}{l}\text { Recommendation is provided in different ways including reminders } \\
\text { of overdue health care tasks, alerts of critical values, prompts for } \\
\text { various active care issues. }\end{array}$ & 0.78 \\
\hline & Conflict of interest ${ }^{*}$ & Software designer or producer is involved in the design of study. & 0.38 \\
\hline & Degree of automation * & $\begin{array}{l}\text { User automatically receives prompts (complete automation) instead } \\
\text { of active initiation of the system by user (incomplete automation). }\end{array}$ & 0.80 \\
\hline \multirow[t]{6}{*}{$\begin{array}{l}\text { Clinician-system } \\
\text { interaction } \\
\text { feature }\end{array}$} & $\begin{array}{l}\text { Automatic provision of recommendation } \\
\text { in paper version as part of clinician } \\
\text { workflow } * *\end{array}$ & $\begin{array}{l}\text { Recommendations printed on paper forms and attached to patient } \\
\text { charts by clinical support staff, so that clinicians do not need to } \\
\text { look for the computer advice. }\end{array}$ & 0.29 \\
\hline & $\begin{array}{l}\text { Automatic provision of recommendation } \\
\text { in electronic version as part of clinician } \\
\text { workflow } * *\end{array}$ & $\begin{array}{l}\text { Electronic recommendations linked to patient charts display } \\
\text { automatically to clinicians when a clinician accesses the database. }\end{array}$ & 0.82 \\
\hline & Data updating via network * & $\begin{array}{l}\text { Data of patient are updated via network link to servers storing } \\
\text { information about all contacts of patient with the hospital. }\end{array}$ & 0.33 \\
\hline & $\begin{array}{l}\text { Request documentation of the reason for } \\
\text { not following recommendation } * *\end{array}$ & $\begin{array}{l}\text { The user is asked to justify the decision of disagreement with a } \\
\text { reason such as "the patient refused" or "I disagree with the } \\
\text { recommendation". }\end{array}$ & 0.56 \\
\hline & $\begin{array}{l}\text { Provision of recommendation at time and } \\
\text { location of decision making ** }\end{array}$ & $\begin{array}{l}\text { Recommendations provided as chart reminders during an } \\
\text { encounter, rather than as monthly reports listing all the patients in } \\
\text { need of services. }\end{array}$ & 0.13 \\
\hline & $\begin{array}{l}\text { Recommendation executed by noting } \\
\text { agreement ** }\end{array}$ & $\begin{array}{l}\text { Computerised system provides recommendations in response to an } \\
\text { order and the user simply clicks "OK" to order the recommended } \\
\text { tests. }\end{array}$ & 0.11 \\
\hline \multirow[t]{3}{*}{$\begin{array}{l}\text { Communication } \\
\text { content features }\end{array}$} & $\begin{array}{l}\text { Provision of a recommendation, not just } \\
\text { an assessment }{ }^{* *}\end{array}$ & $\begin{array}{l}\text { Systems show better actions to perform, rather than simply } \\
\text { providing a diagnosis. }\end{array}$ & 0.11 \\
\hline & $\begin{array}{l}\text { Promotion of action rather than inaction } \\
\text { ** }\end{array}$ & $\begin{array}{l}\text { Systems recommend an alternative view, rather than simply } \\
\text { recommending the order to be cancelled. }\end{array}$ & 0.11 \\
\hline & $\begin{array}{l}\text { Justification of recommendation via } \\
\text { provision of reasoning }{ }^{* *}\end{array}$ & $\begin{array}{l}\text { Recommendation for a check justified by noting date of last exam } \\
\text { and recommended frequency of testing. }\end{array}$ & 0.18 \\
\hline \multirow[t]{5}{*}{$\begin{array}{l}\text { Auxiliary } \\
\text { features }\end{array}$} & $\begin{array}{l}\text { Local user involvement in development } \\
\text { process ** }\end{array}$ & $\begin{array}{l}\text { Recommendation design finalised after testing preliminary versions } \\
\text { of software (beta version) with representatives from targeted user } \\
\text { group. }\end{array}$ & 0.09 \\
\hline & $\begin{array}{l}\text { Provision of recommendations to patients } \\
\text { as well as providers ** }\end{array}$ & $\begin{array}{l}\text { As well as providing chart reminders for clinicians, system generates } \\
\text { postcards that are sent to patients to inform them of existing } \\
\text { recommendation. }\end{array}$ & 0.18 \\
\hline & $\begin{array}{l}\text { Recommendation accompanied by } \\
\text { periodic performance feedback ** }\end{array}$ & $\begin{array}{l}\text { Users are sent e-mails periodically that summarise users compliance } \\
\text { with recommendations. }\end{array}$ & 0.02 \\
\hline & $\begin{array}{l}\text { Recommendation accompanied by } \\
\text { conventional education ** }\end{array}$ & $\begin{array}{l}\text { Implementation of a recommendation is accompanied by a } \\
\text { presentation or an appropriate explanation for following such } \\
\text { suggestion. }\end{array}$ & 0.27 \\
\hline & User training * & $\begin{array}{l}\text { A training period is provided for users to experience the basic } \\
\text { features of the software. }\end{array}$ & 0.22 \\
\hline \multirow[t]{3}{*}{$\begin{array}{l}\text { Guidelines } \\
\text { features }\end{array}$} & Type of guideline* & $\begin{array}{l}\text { Recommendations are focused on preventive or treatment issues or } \\
\text { both options. }\end{array}$ & $\begin{array}{l}0.31 \\
0.62 \\
0.07\end{array}$ \\
\hline & Type of condition* & $\begin{array}{l}\text { Recommendations are oriented towards acute or chronic patients } \\
\text { or both options. }\end{array}$ & $\begin{array}{l}0.16 \\
0.60 \\
0.24\end{array}$ \\
\hline & Type of intervention* & $\begin{array}{l}\text { Recommendations suggest to administrate tests or/and drugs to } \\
\text { patients or to perform other type of intervention on them or both } \\
\text { options. }\end{array}$ & $\begin{array}{l}0.53 \\
0.16 \\
0.31\end{array}$ \\
\hline
\end{tabular}

** Feature referring to Kawamoto

* Feature selected by authors

\# Calculated on the total of 45 studies 
- allocation to study groups (random, 2; quasi-random, 1 ; selected concurrent controls, 0 );

- data analysis and presentation of results (appropriate statistical analysis and clear presentation of results, 2; inappropriate statistical analysis or unclear presentation of results, 1; inappropriate statistical analysis and unclear presentation of results, 0);

- presence of baseline differences between the groups that were potentially linked to study outcomes (no baseline differences present or appropriate statistical adjustments made for differences, 2; baseline differences present and no statistical adjustments made, 1 ; baseline characteristics not reported, 0 );

- objectivity of the outcome (objective outcomes or subjective outcomes with blinded assessment, 2; subjective outcomes with no blinding but clearly defined assessment criteria, 1 ; subjective outcomes with no blinding and poorly defined, 0 );

- completeness of follow-up for the appropriate unit of analysis (> 90\%, 2 ; from $80 \%$ to $90 \%, 1$; $<80 \%$ or not described, 0).

The cut-off value for including an article in our paper was $5 / 10$.

The quality assessment of each study is reported in Table 2.

\section{Statistical Analysis}

Each study, comparing the impact of CCG versus NCCG, was considered as a unit of analysis.

We estimated, within 95\% confidence interval:

- Positive Effect Prevalence, calculated as the proportion of studies showing a positive effect of CCG on the total of selected studies.

- Negative Effect Prevalence, calculated as the proportion of studies not showing any or negative effect of CCG on the total of selected studies.

Chi-square test was performed in order to identify whether the differences between the proportions of the studies' positive and negative effects were statistically significant. The significance level was set at $5 \%$ $(\alpha=0.05)$.

The effect of each specific feature on the process of care was also analysed in a backward logistic regression analysis which was carried out to evaluate the association of features with the positive effect of CCG, adjusting for the following variables:

- publication year, using 1999 (after publication of Shifman's article) as a cut-off year (1994-1999; 20002006);

- design of the study: observational and experimental studies;

- quality of the study, using 7 as cut-off score $(5-7 ; 8$ 10)
Hosmer-Lemeshow test was applied to evaluate the goodness of fit of model. All analyses were carried out using SPSS package, version 13.0.

\section{Results}

A total number of 2,996 articles out of 3,502 was excluded because of the title and the content of abstract. Then, 191 out of 506 studies met the inclusion criteria. Forty-five articles were included in the final selection [14,15,22-64]. (Figure 1). Some of the articles included in Garg's and Kawamoto reviews [6,12] were excluded by our selection [see Additional file 1]. The characteristics of selected studies are shown in Table 3.

Automatic provision of recommendation in electronic version as part of clinician workflow (proportion $=0.82$ ) and Degree of automation (proportion $=0.80$ ) were the most frequent features used in the CCG software described in the selected articles. On the contrary, the least frequent features were Recommendation executed by noting agreement, Provision of a recommendation not just an assessment, Promotion of action rather than inaction (proportion $=0.11$ ) as shown in Table 1 .

Proportions of studies with Positive and Negative Effect of CCG versus NCCG are shown in Figure 2. In the selected 45 articles the positive effect proportion of CCG was 0.64 ( $\mathrm{p}=0.053)$ [see Additional file 2].

The multivariable analysis highlighted two variables as statistically significant predictors of CCG positive impact on the process of care: Automatic provision of recommendation in electronic version as part of clinician workflow (Odds Ratio [OR] = 17.5; 95\% confidence interval [CI]: 1.6-193.7) and Publication Year (OR = 6.7; 95\%CI: 1.3-34.3). Besides, the feature Justification of recommendation via provision of reasoning $(\mathrm{OR}=14.8 ; 95 \% \mathrm{CI}$ : $0.9-224.2)$ resulted marginally significant in logistic analysis.

The goodness of fit of the logistic model was confirmed in the Hosmer-Lemeshow test $(p=0.905)$.

\section{Discussion}

Previous researches $[6,10,11]$ reviewed controlled clinical trials classified within different categories (e.g. drug dose determination, diagnosis, prevention) in order to assess the effects of CDSS on physician's performance and patient's outcomes. Enhancements on clinical performance were reported after the use of these tools. Furthermore, role of specific features of CDSS affecting clinical practice were identified by Kawamoto et al [12].

Our study instead focused on the effectiveness of CCG (a group of CDSS strictly related to the medical decision making). The functionality and the effectiveness of CCG until 1998 had been studied by Shiffman et al. [13]. They reviewed the literature showing that CCG delivered positive effect, but no quantitative and synthetic 
Table 2 Study design and quality assessment of selected articles

\begin{tabular}{|c|c|c|c|c|c|c|c|c|c|}
\hline \multicolumn{10}{|c|}{ Quality assessment } \\
\hline Authors & $\begin{array}{c}\text { Year of } \\
\text { publication }\end{array}$ & Rivista & Study Design & $\begin{array}{l}\text { Method of } \\
\text { allocation } \\
\text { to study } \\
\text { group }\end{array}$ & $\begin{array}{l}\text { Data } \\
\text { analysis } \\
\text { and } \\
\text { results }\end{array}$ & $\begin{array}{l}\text { Presence of baseline } \\
\text { differences between } \\
\text { groups potentially linked } \\
\text { to study outcome }\end{array}$ & $\begin{array}{l}\text { Type of } \\
\text { outcome } \\
\text { measure }\end{array}$ & $\begin{array}{l}\text { Completeness } \\
\text { of follow-up }\end{array}$ & Total \\
\hline Burack & 1997 & Medical Care & Experimental & 2 & 2 & 2 & 2 & 2 & 10 \\
\hline Burack & 1994 & Medical Care & Experimental & 2 & 2 & 2 & 2 & 2 & 10 \\
\hline Butzlaff & 2003 & $\begin{array}{l}\text { Family } \\
\text { Practice }\end{array}$ & Experimental & 2 & 1 & 2 & 0 & 2 & 7 \\
\hline Cannon & 2000 & JAMIA & Experimental & 2 & 2 & 2 & 1 & 2 & 9 \\
\hline Carton & 2002 & $\begin{array}{l}\text { Clinical } \\
\text { Radiology }\end{array}$ & $\begin{array}{l}\text { Observational } \\
\text { (time series) }\end{array}$ & 0 & 1 & 0 & 2 & 2 & 5 \\
\hline Dayton & 2000 & $\begin{array}{l}\text { Medical } \\
\text { Decision } \\
\text { Making }\end{array}$ & Experimental & 2 & 1 & 0 & 0 & 2 & 5 \\
\hline Demakis & 2000 & JAMA & Experimental & 2 & 2 & 2 & 2 & 2 & 10 \\
\hline Derose & 2005 & $\begin{array}{c}\text { American } \\
\text { Journal } \\
\text { Manag Care }\end{array}$ & Experimental & 2 & 1 & 0 & 2 & 2 & 7 \\
\hline Dexter & 2001 & $\begin{array}{l}\text { New England } \\
\text { Journal of } \\
\text { Medicine }\end{array}$ & Experimental & 2 & 2 & 2 & 2 & 2 & 10 \\
\hline Durieux & 2000 & JAMA & $\begin{array}{c}\text { Observational } \\
\text { (time series) }\end{array}$ & 0 & 1 & 1 & 2 & 2 & 6 \\
\hline Feldman & 2005 & $\begin{array}{l}\text { Health } \\
\text { Services } \\
\text { Research }\end{array}$ & Experimental & 1 & 1 & 2 & 1 & 2 & 7 \\
\hline Feldstein & 2006 & $\begin{array}{c}\text { Journal } \\
\text { American } \\
\text { Geriatric Soc }\end{array}$ & Experimental & 2 & 1 & 2 & 2 & 2 & 9 \\
\hline Filippi & 2003 & Diabetes Care & Experimental & 2 & 1 & 0 & 2 & 2 & 7 \\
\hline Fitzamaurice & 2000 & $\begin{array}{c}\text { Arch Intern } \\
\text { Med }\end{array}$ & Experimental & 2 & 1 & 2 & 1 & 2 & 8 \\
\hline Frank & 2004 & Australia & Experimental & 1 & 1 & 2 & 2 & 2 & 8 \\
\hline Hetlevik & 1999 & $\begin{array}{l}\text { Scand J } \\
\text { Health Care }\end{array}$ & Experimental & 2 & 1 & 2 & 2 & 1 & 8 \\
\hline Hetlevik & 2000 & $\begin{array}{l}\text { Int J Technol } \\
\text { Assess Health } \\
\text { Care }\end{array}$ & Experimental & 2 & 1 & 2 & 2 & 0 & 7 \\
\hline Jousimaa & 2002 & $\begin{array}{l}\text { Int J Technol } \\
\text { Assess Health } \\
\text { Care }\end{array}$ & Experimental & 2 & 1 & 2 & 2 & 1 & 8 \\
\hline Kitahata & 2003 & $\begin{array}{l}\text { Clinical } \\
\text { Infectious } \\
\text { Disease }\end{array}$ & $\begin{array}{l}\text { Observational } \\
\text { (before and } \\
\text { after) }\end{array}$ & 0 & 1 & 2 & 2 & 2 & 7 \\
\hline Kucher & 2005 & $\begin{array}{l}\text { The New } \\
\text { England } \\
\text { Journal of } \\
\text { medicine }\end{array}$ & Experimental & 2 & 1 & 0 & 2 & 2 & 7 \\
\hline Lafata & 2002 & JGIM & Experimental & 2 & 2 & 2 & 2 & 2 & 10 \\
\hline Lobach & 1997 & Am J Med & Experimental & 2 & 0 & 2 & 2 & 2 & 8 \\
\hline Raebel & 2005 & $\begin{array}{l}\text { Arch Intern } \\
\text { Med }\end{array}$ & Experimental & 2 & 1 & 2 & 2 & 2 & 9 \\
\hline McCowan & 2001 & $\begin{array}{c}\text { Medical } \\
\text { Informatics }\end{array}$ & Experimental & 2 & 2 & 2 & 1 & 0 & 7 \\
\hline
\end{tabular}


Table 2: Study design and quality assessment of selected articles (Continued)

\begin{tabular}{|c|c|c|c|c|c|c|c|c|c|}
\hline McMullin & 2004 & $\begin{array}{l}\text { Annals of } \\
\text { Family } \\
\text { Medicine }\end{array}$ & $\begin{array}{l}\text { Observational } \\
\text { (retrospective } \\
\text { cohort study) }\end{array}$ & 0 & 1 & 0 & 2 & 2 & 5 \\
\hline Medow & 2001 & $\begin{array}{l}\text { Medical } \\
\text { Decision } \\
\text { Making }\end{array}$ & Experimental & 2 & 2 & 0 & 0 & 2 & 6 \\
\hline Meigs & 2003 & Diabetes Care & Experimental & 2 & 1 & 2 & 2 & 2 & 9 \\
\hline Montgomery & 2000 & BMJ & Experimental & 2 & 2 & 2 & 1 & 1 & 8 \\
\hline Mosen & 2004 & Chest & $\begin{array}{l}\text { Observational } \\
\text { (before and } \\
\text { after) }\end{array}$ & 0 & 2 & 2 & 2 & 2 & 8 \\
\hline Murtaugh & 2005 & $\begin{array}{l}\text { Health } \\
\text { Services } \\
\text { Research }\end{array}$ & Experimental & 2 & 1 & 2 & 1 & 2 & 8 \\
\hline Overhage & 1996 & $\begin{array}{l}\text { Arch Intern } \\
\text { Med }\end{array}$ & Experimental & 1 & 2 & 2 & 2 & 2 & 9 \\
\hline Overhage & 1997 & JAMIA & Experimental & 2 & 1 & 2 & 2 & 2 & 9 \\
\hline Poller & 1993 & J Clin Pathol & Experimental & 2 & 2 & 1 & 2 & 2 & 9 \\
\hline Rood & 2005 & JAMIA & Experimental & 2 & 2 & 1 & 2 & 2 & 9 \\
\hline Rossi & 1997 & JGIM & Experimental & 2 & 1 & 2 & 2 & 2 & 9 \\
\hline Safran & 1995 & Lancet & Experimental & 0 & 2 & 2 & 2 & 2 & 8 \\
\hline Schriger & 1997 & JAMA & $\begin{array}{l}\text { Observational } \\
\text { (interrupted } \\
\text { time series) }\end{array}$ & 1 & 1 & 2 & 2 & 2 & 8 \\
\hline Sequist & 2005 & JAMIA & Experimental & 2 & 1 & 2 & 2 & 2 & 9 \\
\hline Shojonia & 1998 & JAMIA & Experimental & 2 & 2 & 0 & 2 & 2 & 8 \\
\hline Steele & 2005 & $\begin{array}{l}\text { American } \\
\text { Journal of } \\
\text { Preventive } \\
\text { Medicine }\end{array}$ & Experimental & 0 & 1 & 0 & 2 & 2 & 5 \\
\hline Thomas & 1999 & $\begin{array}{c}\mathrm{J} \text { Med } \\
\text { Internet Res }\end{array}$ & Experimental & 2 & 1 & 0 & 1 & 2 & 6 \\
\hline Tierney & 2003 & JGIM & Experimental & 2 & 1 & 2 & 2 & 2 & 9 \\
\hline Turner & 1994 & $\begin{array}{l}\text { Arch Intern } \\
\text { Med }\end{array}$ & Experimental & 2 & 1 & 2 & 2 & 1 & 8 \\
\hline Williams & 1998 & $\begin{array}{l}\text { Arch Fam } \\
\text { Med }\end{array}$ & Experimental & 2 & 1 & 0 & 2 & 2 & 7 \\
\hline Zanetti & 2003 & $\begin{array}{c}\text { Infection } \\
\text { control and } \\
\text { hospital } \\
\text { epidemiology }\end{array}$ & Experimental & 2 & 2 & 2 & 2 & 2 & 10 \\
\hline
\end{tabular}

analysis were carried out. Our contribution provides an updated, systematic and quantitative analysis aiming to understand the design factors which are responsible for the success or the failure of computer-based guidelines compared with NCCG.

The resulting evidence showed that the use of CCG seems to have a significant impact on the process of care. In addition to qualitative evidence reported by Shiffman [13], the multivariable analysis highlighted the positive effect of the presence of an operating CCG system, characterized by the automatic provision of recommendation in electronic form as part of clinician workflow. This system is designed for providing automatic support to clinicians so that they don't need to look for computer advices. The system automatically provides support on clinical or administrative task and recommends execution or avoiding of it during the clinical process, (e.g. automatic recommendation of executing prophylaxis in patients at risk of deep-vein thrombosis [48]), and in decisions, such as the selection from a set of potential alternatives based on predefined criteria (e.g. automatic prompt of further assessment for potential Latent Tuberculosis Infection in patients selected according to specific criteria [38]) [65]. 
Articles' exclusion based on title and abstract (2996):

- Not original research articles

- Interventions not targeted to clinicians or others

health care providers

Excluded articles not meeting the search criteria

after a full-text reading (315):

- No concurrent control group

- Study population $<18$ years

- No guidelines recognized by national or

international scientific institution

Excluded studies not meeting the search criteria

after further reading (124):

-Does not meet quality score of 5 points

Figure 1 Selection process of studies on computerized guidelines

Table 3 Characteristics of selected studies

\begin{tabular}{|c|c|c|c|c|}
\hline \multicolumn{2}{|c|}{ Variables } & \multicolumn{3}{|c|}{ Countries } \\
\hline & & Europe & USA & Oceania \\
\hline \multirow[t]{2}{*}{ Study design } & Observational & $2(33.3 \%)$ & $4(66.7 \%)$ & $0(0.0 \%)$ \\
\hline & Experimental & $9(23.1 \%)$ & $29(74.3 \%)$ & $1(2.6 \%)$ \\
\hline \multirow[t]{2}{*}{ Type of patients } & Inpatient & $2(28.6 \%)$ & $5(71.4 \%)$ & $0(0.0 \%)$ \\
\hline & Outpatient & $4(23.5 \%)$ & $12(70.6 \%)$ & $1(5.9 \%)$ \\
\hline \multirow[t]{2}{*}{ Guidelines receivers } & Physicians & $10(28.6 \%)$ & $24(68.6 \%)$ & $1(2.9 \%)$ \\
\hline & Other care givers & $1(10.0 \%)$ & $9(90.0 \%)$ & $0(0 \%)$ \\
\hline \multirow[t]{2}{*}{ Population of study } & Simulated & $1(25.0 \%)$ & $3(75.0 \%)$ & $0(0.0 \%)$ \\
\hline & Real & $10(24.4 \%)$ & $30(73.2 \%)$ & $1(3.3 \%)$ \\
\hline \multirow[t]{2}{*}{ Type of centres involved in the study } & Non-academic & $5(22.7 \%)$ & $17(77.3 \%)$ & $0(0.0 \%)$ \\
\hline & Academic & $5(25.0 \%)$ & $15(75.0 \%)$ & $0(0.0 \%)$ \\
\hline \multirow[t]{2}{*}{ Number of centres involved in the study } & Multicentric & $7(36.8 \%)$ & $11(57.9 \%)$ & $1(5.3 \%)$ \\
\hline & Monocentric & $4(15.4 \%)$ & $22(84.6 \%)$ & $0(0.0 \%)$ \\
\hline \multirow[t]{3}{*}{ Type of guideline } & Preventive & $1(7.1 \%)$ & $12(85.7 \%)$ & $1(7.1 \%)$ \\
\hline & Treatment & $9(32.1 \%)$ & $19(67.9 \%)$ & $0(0.0 \%)$ \\
\hline & Both & $1(33.3 \%)$ & $2(66.7 \%)$ & $0(0.0 \%)$ \\
\hline \multirow[t]{3}{*}{ Type of condition } & Acute & $2(28.6 \%)$ & $5(71.4)$ & $0(0.0 \%)$ \\
\hline & Chronic & $6(22.2 \%)$ & $21(77.8 \%)$ & $0(0.0 \%)$ \\
\hline & Both & $3(27.3 \%)$ & $7(63.6 \%)$ & $1(9.1 \%)$ \\
\hline \multirow[t]{3}{*}{ Type of intervention } & Test or/and drugs & 7 (29.2\%) & $17(70.8 \%)$ & $0(0.0 \%)$ \\
\hline & Other intervention & $1(14.3 \%)$ & $6(85.7 \%)$ & $0(0.0 \%)$ \\
\hline & Both & $3(21.4 \%)$ & $10(71.4)$ & $1(7.1 \%)$ \\
\hline
\end{tabular}




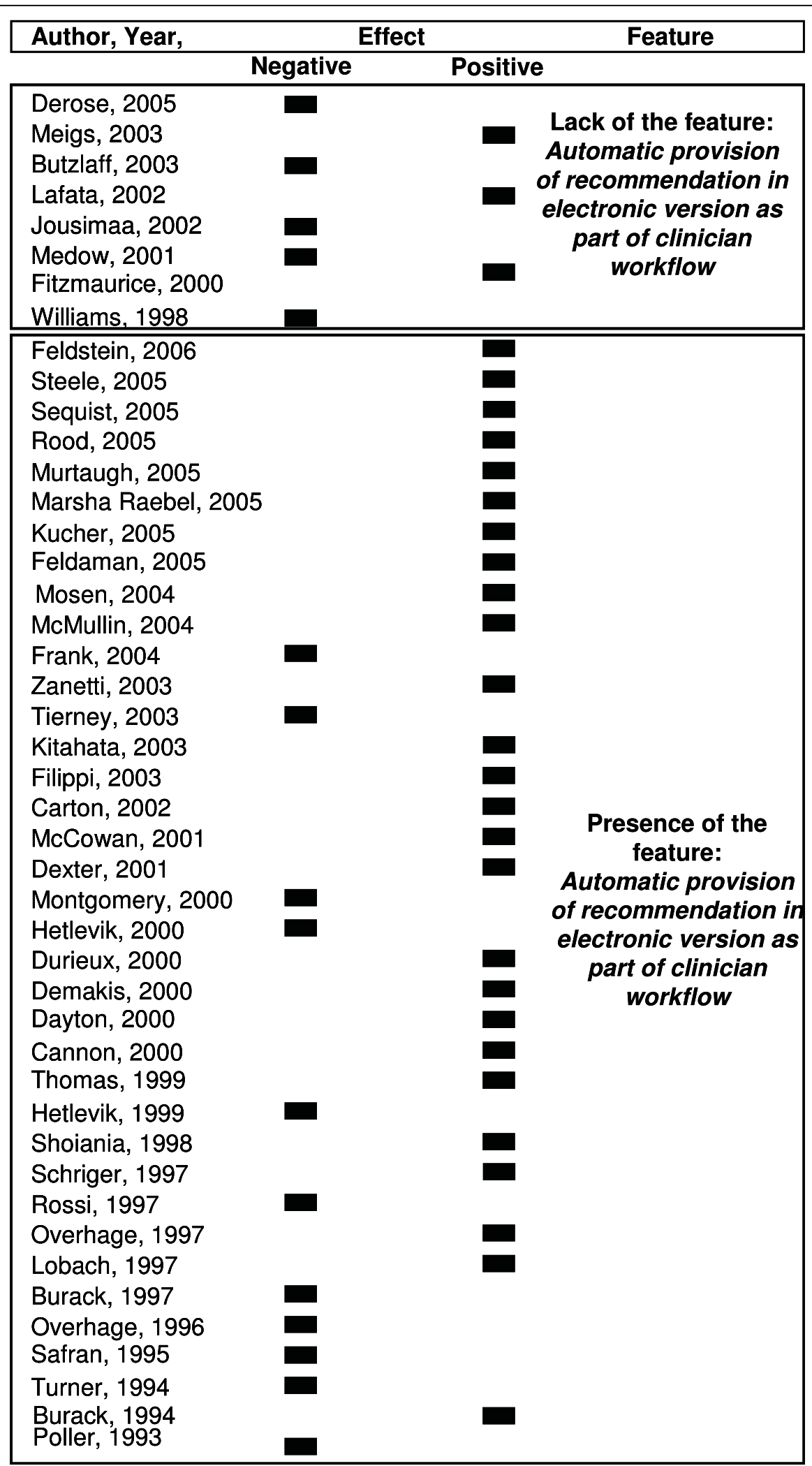

Figure 2 Plot of the effect stratified by "Automatic provision of recommendation in electronic version as part of clinician workflow" feature. 
The positive effect might be related to time saving for clinicians, facilitation of the information retrieval and integration among different users.

The evidence of increased probability of positive effect for CCG, showed after 1999, might suggest that the improvement of the process of care may be related to the development of more automated CCG systems $[66,67]$.

The physicians' involvement in decisions regarding clinical recommendations, even though marginally significant in the multivariable analysis, might be a key element for the effective organization of the whole process of care, relating to the improvement of the adherence of physicians to guidelines. This aspect is coherent to the active roles that physicians should play in Clinical Governance context $[68,69]$.

Some limits of our study might be related to the lack of quantitative estimate of specific outcomes linked to clinical conditions. However, the evaluation of synthetic quantitative measures of CCG effect was unfeasible because of the high heterogeneity of analysed guidelines, population and outcomes. However, our work presents the synthetic result on the effectiveness of CCG, providing a quantitative and reproducible evaluation.

\section{Conclusions}

Findings of this paper suggest clinicians, managers and other health care decision makers which features of CCG might improve the structure of an electronic system in health care settings. At the same time, the implementation of CCG may be integrated with more training and investment in user friendly hardware and software. Therefore, specific studies should be carried out to evaluate the cost-effectiveness of implementing CCG systems.

Additional file 1: Appendix 1. Articles included in Garg and Kawamoto reviews and excluded in our review.

Click here for file

[http://www.biomedcentral.com/content/supplementary/1472-6963-10-2S1.DOC]

Additional file 2: Appendix 2. List of outcomes of selected articles.

Click here for file

[http://www.biomedcentral.com/content/supplementary/1472-6963-10-2S2.XLS ]

\section{Abbreviations}

CCG: computerized clinical guidelines; CDSSs: computerized clinical decision support systems; NCCG: non-computerized clinical guidelines.

\section{Acknowledgements}

Funding for this project "Development, application and effectiveness valuation of an informative system to support the clinical research" was provided by the Italian Ministry of Health.

\section{Author details}

'Department of Public Health-Università Cattolica Sacro Cuore-Rome, Largo Francesco Vito 1, 00168, Rome, Italy. ${ }^{2}$ San Filippo Neri-Hospital Trust-Rome, Italy, Piazza di Santa Maria della Pietà 5, 00135, Rome, Italy. ${ }^{3}$ Oncological Referral Center of Basilicata (IRCCS CROB), Via Padre Pio 1, 85028, Rionero in Vulture, Potenza, Italy.

\section{Authors' contributions}

GD, LP and WR contributed to the conception of this paper; GD, LP RG, LoS designed the study. SCC and RA selected articles that met the inclusion criteria and extracted data. LS, LP conducted the statistical analysis. All authors made substantial contributions to the interpretation of results and have seen and approved the final version.

\section{Competing interests}

The authors declare that they have no competing interests.

Received: 4 March 2009

Accepted: 4 January 2010 Published: 4 January 2010

\section{References}

1. Field MJ, Lohr KN, eds: Clinical practice guidelines: directions for a new program. Washington, DC: National Academy Press 1990.

2. Shekelle P, Eccles MP, Grimshaw JM, Woolf SH: When should clinical guidelines be updated?. BMJ 2001, 323(7305):155-7.

3. Shekelle PG, Woolf SH, Eccles M, Grimshaw J: Clinical guidelines: developing guidelines. BMJ 1999, 318(7183):593-6.

4. Steinbrook R: Guidance for guidelines. N Engl J Med 2007, 356(4):331-3.

5. Wyatt J, Spiegelhalter D: Field trials of medical decision-aids: potential problems and solutions. Proceedings of the Annual Symposium on Computer Application in Medical Care: 17-20 November 1991; Washington Clayton P 1991, 3-7.

6. Garg AX, Adhikari NKJ, McDonald H, Rosas-Arellano MP, Devereaux PJ, Beyene J, Sam J, Haynes B: Effects of Computerized Clinical Decision Support Systems on practitioner performance and patient outcomes. JAMA 2005, 293:1223-1238.

7. Shortliffe EH: Computer programs to support clinical decision making. JAMA 1987, 258(1):61-6.

8. Waitman $L R$, Miller RA: Pragmatics of implementing guidelines on the front lines. J Am Med Inform Assoc 2004, 11(5):436-8.

9. Wang D, Peleg M, Tu SW, Shortliffe EH, Greenes RA: Representation of clinical practice guidelines for computer-based implementations. Stud Health Technol Inform 2001, 84(Pt 1):285-9.

10. Hunt DL, Haynes RB, Hanna SE, Smith K: Effects of computer-based clinical decision support systems on physicians performance and patient outcomes. J Am Med Assoc 1998, 280:1339-1346.

11. Johnston ME, Langton $K B$, Haynes RB, Mathieu A: Effects of computerbased clinical decision support systems on clinician performance and patient outcome. A critical appraisal of research. Ann Intern Med 1994, 120(2):135-42

12. Kawamoto K, Houlihan CA, Balas EA, Lobach DF: Improving clinical practice using clinical decision support systems: a systematic review of trials to identify features critical to success. BMJ 2005, 330:765-773.

13. Shiffman RN, Liaw Y, Brandt CA, Corb GJ: Computer-based guideline implementation system: a systematic review of functionality and effectiveness. JAMIA 1999, 6:104-114.

14. Overhage JM, Tierney WM, McDonald CJ: Computer reminders to implement preventive care guidelines for hospitalized patients. Arch Intern Med 1996, 156:1551-1556.

15. Raebel MA, Lyons EE, Chester EA, Bodily MA, Kelleher JA, Long CL, Miller C, Magid DJ: Improving laboratory monitoring at initiation of drug therapy in ambulatory care. Arch Intern Med 2005, 165:2395-2401.

16. Cabana MD, Rand CS, Becher OJ, Rubin HR: Reasons for pediatrician nonadherence to asthma guidelines. Arch Pediatr Adolesc Med 2001, 155(9):1057-62.

17. Cabana MD, Ebel BE, Cooper-Patrick L, Powe NR, Rubin HR, Rand CS: Barriers pediatricians face when using asthma practice guidelines. Arch Pediatr Adolesc Med 2000, 54(7):685-93.

18. Weinberger M: Seventeen Years of Asthma Guidelines: why Hasn't the Outcome Improved for Children?. J Pediatr 2009, 54(6):786-8. 
19. Haynes RB, Walker C: Computer-aided quality assurance. Arch Intern Med 1987, 147:1297-1301.

20. Damiani G, Pinnarelli L, Sammarco A, Sommella L, Francucci M, Ricciardi W: Postoperative Pulmonary Function inOpen versus Laparoscopic Cholecystectomy: A Meta-Analysis of the Tiffenau Index Dig. Surg 2008, 25:1-7.

21. Chalmers TC, Smith H Jr, Blackburn B, Silverman B, Schroeder B, Reitman D, Ambroz: A method for assessing the quality of a randomized control trial. A Control Clin Trials 1981, 2(1):31-49.

22. Jousimaa J, Makela M, Kunnamo I, MacLennan G, Grimsha JM: Primary care guidelines on consultation practices: the effectiveness of computerized versus paper-based versions. Int J Technol Assess Health Care 2002, 18:586-596.

23. Rood E, Bossman RJ, Spoel Van Der Jl, Taylor P, Zandstra DF: Use of a computerized guideline for glucose regulation in the intensive care unit improved both guideline adherence and glucose regulation. JAMIA 2005, 12:172-180.

24. Butzlaff M, Vollmar HC, Floer B, Koneczny N, Isfort J, Lange S: Learning with computerized guidelines in general practice? A randomized controlled trial. Fam Pract 2003, 21:183-188.

25. Medow MA, Wilt TJ, Dysken S, Hillson SD, Woods S, Borowsky SJ: Effect of written and computerized decision support aids for the U.S. Agency for Health Care Policy and Research depression guidelines on the evaluation of hypothetical clinical scenarious. Med Decis Making 2001, 21:344-356.

26. Durieux P, Nizard R, Ravaud P, Mounier N, Lepage E: A Clinical Decision Support System for prevention of venous thromboembolism. Effect on physician behaviour. JAMA 2000, 283:2816-2821.

27. Rossi RA, Every NR: A computerized intervention to decrease the use of calcium channel blockers in hypertension. J Gen Intern Med 1997, 12:672-678.

28. Safran C, Rind DM, Davis RB, Ives D, Sands DZ, Currier J, Slack WV Makadon HJ, Cotton DJ: Guidelines for management of HIV infection with compute-based patient's record. Lancet 1995, 346:341-346.

29. Dexter PR, Perkins S, Overhage M, Maharry K, Kohler RB, McDonald CJ: A computerized reminder system to increase the use of preventive care for hospitalized patients. N Engl J Med 2001, 345:965-970.

30. Mosen D, Elliott CG, Egger MJ, Mundorff M, Hopkins J, Patterson R, Gardner RM: The effect of a computerized reminder system on the prevention of postoperative venous thromboembolism. Chest 2004, 125:1635-1641.

31. Shojania KG, Yokoe D, Platt R, Fiskio J, Ma'luf N, Bates DW: Reducing vancomycin use utilizing a computer guideline: results of a randomized controlled trial. JAMIA 1998, 5:554-562.

32. Schriger DL, Baraff $L$, Rogers $W H$, Cretin S: Implementing of clinical guidelines using a computer charting system. Effect on the initial care of health care workers exposed to body fluids. JAMA 1997, 278:1585-1590.

33. Thomas KW, Dayton CS, Peterson MW: Evaluation of internet-based clinical decision support systems. JMIR 1999, 1:6-36.

34. Carton M, Auvert B, Guerini H, Boulard JC, Heautot JF, Landre MF Beauchet A, Sznajderi M, Brun-Ney D, Chagnon S: Assessment of radiological referral practice and effect of computer-based guidelines on radiological requests in two emergency departments. Clin Radiol 2002, 57:123-128.

35. Lobach DF, Hammond WE: Computerized decision support based on a clinical practice guideline improves compliance with care standards. Am J Med 1997, 102:89-98.

36. Tierney WM, Overhage JM, Murray MD, Harris LE, Zhou XH, Eckert GJ, Smith FE, Nienaber N, McDonald CJ, Wolinsky FD: Effects of computerized guidelines for managing heart disease in primary care. J Gen Intern Med 2003, 18:967-976.

37. McMullin ST, Lonergan TP, Rynearson CS, Doerr TD, Veregge PA, Scanlan ES: Impact of an evidence-based computerized decision support system on primary care prescription costs. Ann Fam Med 2004, 2:494-498.

38. Steele AW, Eisert S, Davidson A, Sandison T, Lyons P, Garrett N, Gabow P, Ortiz E: Using computerized clinical decision support for latent tuberculosis infection screening. Am J Prev Med 2005, 28:281-284.

39. Dayton CS, Ferguson S, Hornick DB, Peterson MW: Evaluation of an internet-based decision-support system for applying the ATS/CDC guidelines for tuberculosis preventive therapy. Med Decis Making 2000, 20:1-6.

40. Overhage JM, Tierney WM, Zhou XA, McDonald CJ: A randomized trial of "corollary orders" to prevent errors of omission. JAMIA 1997, 4:364-375.

41. Filippi A, Sabatini A, Badioli L, Samani F, Mazzaglia G, Catapano A, Cricelli C: Effects of an automated electronic reminder in changing the antiplatelet drug-prescribing behavior among italian general practitioners in diabetic patients. Diabetes Care 2003, 26:1497-1500.

42. Turner RC, Peden JG, O'Brien K: Patient-carried card prompts vs computer-generated prompts to remind private practice physicians to perform health maintenance measures. Arch Intern Med 1994, 154:1957-1960.

43. Burack RC, Phyllis AG: Promoting screening mammography in inner-city settings. The sustained effectiveness of computerized reminders in a randomized controlled trial. Med Care 1997, 35:921-931.

44. Burack RC, Phyllis AG, George J, Stengle W, Warbasse L, Moncrease A: Promoting screening mammography in inner-city settings: a randomized controlled trial of computerized reminders as a component of a program to facilitate mammography. Med Care 1994, 32:609-624.

45. Sequist TD, Gandhi TK, Karson AS, Fiskio JM, Bugbee D, Sperling M, Cook EF, Orav EJ, Fairchild DJ, Bates DW: A randomized trial of electronic clinical reminders to improve quality of care for diabetes and coronary artery disease. JAMIA 2005, 12:431-437.

46. Derose SF, Dudl JR, Benson VM, Contreas R, Nakahiro RK, Ziel FH: Point-ofservice reminders for prescribing cardiovascular medications. Am J Manag Care 2005, 11:298-304.

47. Kitahata MM, Dillingham PW, Chaiyakunapruk N, Buskin SE, Jones JL, Harrington RD, Hooton TM, Holmes KK: Electronic human immunodeficiency virus (HIV) clinical reminder system improves adherence to practice guidelines among the University of Washington HIV study cohort. Clin Infect Dis 2003, 36:803-811.

48. Kucher N, Koo S, Quiroz R, Cooper JM, Paterno MD, Soukonnikov B, Goldhaber SZ: Electronic alerts to prevent venous thromboembolism among hospitalized patients. N Engl J Med 2005, 352:969-977.

49. Feldman PH, Murtaugh CM, Pezzin LE, McDonald MV, Peng TR: Just-in-time evidence-based e-mail "reminders" in home health care: impact on patient outcomes. Health Serv Res 2005, 40:865-885.

50. Frank O, Litt J, Beilby J: Opportunistic electronic reminders. Aust Fam Physician 2004, 33:87-90.

51. Feldstein A, Elmer PJ, Smith DH, Herson M, Orwoll E, Chen C, Aickin M, Swain MC: Electronic medical record reminder improves osteoporosis management after a fracture: a randomized, controlled trial. J Am Geriatr Soc 2006, 54:450-457.

52. Williams RB, Boles M, Johnson RE: A patient-initiated system for preventive health care. Arch Fam Med 1998, 7:338-345.

53. Zanetti G, Flanagan HL, Cohn LH, Giardina R, Platt R: Improvement of intraoperative antibiotic prophylaxis in prolonged cardiac surgery by automated alerts in the operating room. Infect Control Hosp Epidemiol 2003, 24:13-16

54. Demakis JG, Beauchamp C, Cull WL, Denwood R, Eisen SA, Lofgren R, Nichol K, Woolliscroft J, Henderson WG: Improving residents' compliance with standards of ambulatory care. JAMA 2000, 284:1411-1416.

55. Hetlevik I, Holmen J, Kruger O: Implementing clinical guidelines in the treatment of hypertension in general practice. Scand J Prim Health Care 1999, 17:35-40.

56. Hetlevik I, Holmen J, Kruger $\mathrm{O}$, Kristensen $\mathrm{P}$, Iversen $\mathrm{H}$, Furuseth $\mathrm{K}$. Implementing clinical guidelines in the treatment of diabetes mellitus in general practice. Int J Technol Assess Health Care 2000, 16:210-227.

57. Murtaugh CM, Pezzin LE, McDonald MV, Feldman PH, Peng TR: Just-in-time evidence-based e-mail "reminders" in home health care: impact on nurse practices. Health Serv Res 2005, 40:849-864.

58. Lafata JE, Baker AM, Divine GW, McCarthy BD, Xi H: The use of computerized birthday greeting reminders in the management of diabetes. J Gen Intern Med 2002, 17:521-530.

59. Fitzmaurice DA, Hobbs FDR, Murray ET, Holder RL, Allan TF, Rose PE: Oral anticoagulation management in primary care with the use of computerized decision support and near-patient testing. Arch Intern Med 2000, 160:2343-2348.

60. Poller $L$, Wright $D$, Rowlands M: rospective comparative study of computer programs used for management of warfarin. J Clin Pathol 1993, 46:299-303. 
61. Meigs JB, Cagliero E, Dubey A, Murphy-Sheehy P, Gildesgame C, Chueh H, Barry M, Singer DE, Nathan MD: A controlled trial of web-based diabetes disease management. Diabetes Care 2003, 26:750-757.

62. Montgomery AA, Fahey T, Peters TJ, Maclntosh C, Sharp DJ: Evaluation of computer based clinical decision support system and risk chart for management of hypertension in primary care: randomised controlled trial. BMJ 2000, 320:686-690.

63. Cannon DS, Allen SN: A comparison of the effects of computer and manual reminders on compliance with a mental health clinical practice guideline. JAMIA 2000, 7:196-203.

64. McCowan C, Neville RG, Ricketts W, Warner FC, Hoskins G, Thomas GE: Lessons from a randomized controlled trial designed to evaluate computer decision support software to improve the management of asthma. Med Inform 2001, 26(3):191-201.

65. Wang D, Peleg M, Tu SW, Boxwala AA, Greenes RA, Patel VL, Shortliffe EH: Representation primitives, process models and patient data in computer-interpretable clinical practice guidelines: a literature review of guideline representation models. Int J Med Inform 2002, 68(1-3):59-70.

66. Isern D, Moreno A: Computer-based execution of clinical guidelines: a review. Int J Med Inform 2008, 77(12):787-808.

67. Goldstein MK: Using health information technology to improve hypertension management. Curr Hypertens Rep 2008, 10(3):201-7.

68. Scally $G$, Donaldson $L$ : Clinical governance and the drive for quality improvement in the new NHS in England. BMJ 1998, 317:61-65.

69. Halligan A, Donaldson LJ: Implementing clinical governance: turning vision into reality. BMJ 2001, 322:1413-1417.

\section{Pre-publication history}

The pre-publication history for this paper can be accessed here:http://www. biomedcentral.com/1472-6963/10/2/prepub

doi:10.1186/1472-6963-10-2

Cite this article as: Damiani et al: The effectiveness of computerized clinical guidelines in the process of care: a systematic review. BMC Health Services Research 2010 10:2.

\section{Submit your next manuscript to BioMed Central and take full advantage of:}

- Convenient online submission

- Thorough peer review

- No space constraints or color figure charges

- Immediate publication on acceptance

- Inclusion in PubMed, CAS, Scopus and Google Scholar

- Research which is freely available for redistribution 